\title{
THE OPTO-ELECTRONIC PROPERTIES AND MOLECULAR DESIGN OF NEW MATERIALS BASED ON PYRROLE. DFT STUDY
}

\author{
H. Toufik ${ }^{1}$, S. M. Bouzzine ${ }^{2,3}$, O. Ninis ${ }^{1,4}$, M. Aberkane ${ }^{4}$, F. Lamchouri ${ }^{1}$, M. Hamidi ${ }^{2}$, M. Bouachrine ${ }^{1 *}$ \\ ${ }^{1}$ UMIM, Faculté Polydisciplinaire de TAZA, BP. 1223, Place de la gare, Taza, Maroc \\ ${ }^{2}$ UCTA, Faculté des Sciences et Techniques, B. P. 509 Boutalamine, Errachidia, Maroc; \\ 3 Trainings Center for Teachers, (CFI) BP 8, Errachidia, \\ ${ }^{4}$ LIMAO, Faculté Polydisciplinaire de Taza, BP. 1223, Place de la gare, Taza, Maroc \\ ${ }^{*}$ Corresponding author, e-mail: bouachrine@gmail.com
}

(Received November 06, 2010; received in final form January 11, 2011)

\begin{abstract}
A study on the geometries and electronic properties of new conjugated compounds based on pyrrole in neutral and doped states was carried out. The theoretical ground-state geometry and electronic structure of the studied molecules were obtained by the DFT method at the B3LYP level with a $6-31 \mathrm{G}(\mathrm{d})$ basis set. The optoelectronic properties were determined by the $\mathrm{ZINDO} / \mathrm{s}$ and TD//B3LYP/6-31G(d) calculations performed on the B3LYP/6-31(d) optimized geometries. The effects of the substituents and the doping process on the geometries and electronic properties of these materials are discussed. The results of this study demonstrate how the electronic properties can be tuned by the backbone ring or side group and suggest these compounds as good candidates for opto-electronic applications

Key words: $\pi$-conjugated oligomers, oligopyrrole, DFT, polaron, bipolaron, electronic properties, gap energy.
\end{abstract}

PACS number(s): 71.20.Rv, 71.15.-m, 71.15.Mb

\section{INTRODUCTION}

Organic $\pi$-conjugated materials based on a heterocyclic ring such as polypyrrole or polythiophene have a wide interest as materials with interesting optical, nonlinear optical and electrical conduction properties [1-4]. These materials are desirable for electronic applications and have been actively researched in the past decade because of their interesting potential applications in the film transistors [1], electroluminescent diodes [2], lasers [3], sensors [4] and photovoltaic cells [5].

Polypyrrole is one of the most studied $\pi$-conjugated polymers. It exhibits high conductivity when it is doped $[6,7]$ as well as a large third-order nonlinear optical response [8]. Interest has also focused on the applications as cathode materials for rechargeable batteries [9], gaz sensors [10], selective biosensors [11] electromagnetic shielding materials [12], ion-exchange chromatography resins [13], membranes [14], and as electro-rheological materials [15].

Recently, increasing interests have been paid to conjugated polymers and oligomers based on pyrrole. The substitution of pyrrole in 3 or 4 positions will increase the solubility of the corresponding polymers and on the other hand will also affect the electronic states of the corresponding polypyrrole. Consequently, the introduction of electron donating substituents at the $\beta$ positions of pyrrole might be an interesting strategy to prevent defects and predict the desirable electro-optical properties of the studied polypyrrole.

Whereas polypyrrole obtained are highly amorphous, oligopyrroles are rather not amorphous and can be synthesized as well-defined compounds. Moreover, these oligomers provide interesting models for our understanding of the structural and electronic peculiarities which control the charge transport and optical properties in parent polymers [17]. These materials are currently under intensive investigation for many applications in optoelectronics. One of the most important factors of controlling physical properties is the band gap $(\mathrm{Eg})$, which is the current topic of research. In particular, the materials with a low band gap are desired in optoelectronic applications [18]. Many ways have been used to modulate this parameter as a modification of the chemical structure or doping process.

In this regard, theoretical studies of oligopyrroles certainly facilitate the knowledge of polymeric structure. Theoretical studies on the electronic structure of conjugated heterocyclic polymers and oligomers have been contributed to rationalize the properties of the known polymers [19] and to predict those of yet unknown ones [20]. The smallest oligomers can play also an important role in our understanding of the charge transport mechanism and physical properties of polymers.

In this work, we are going to carry out the DFT calculations and to discuss the structural and electronic properties of neutral and doped oligopyrrole derivatives (Fig. 1). The results are discussed in comparison with the properties of the doped oligomers. We are particularly interested in the effect of the introduction of substituents in the 3 and 4 positions of pyrrole and the influence of replacement of sulfur atom with oxygen on structural and electronic properties through comparing the energies of HOMO, LUMO and Gap energies of the studying molecules with those of the polypyrrole [21]. 


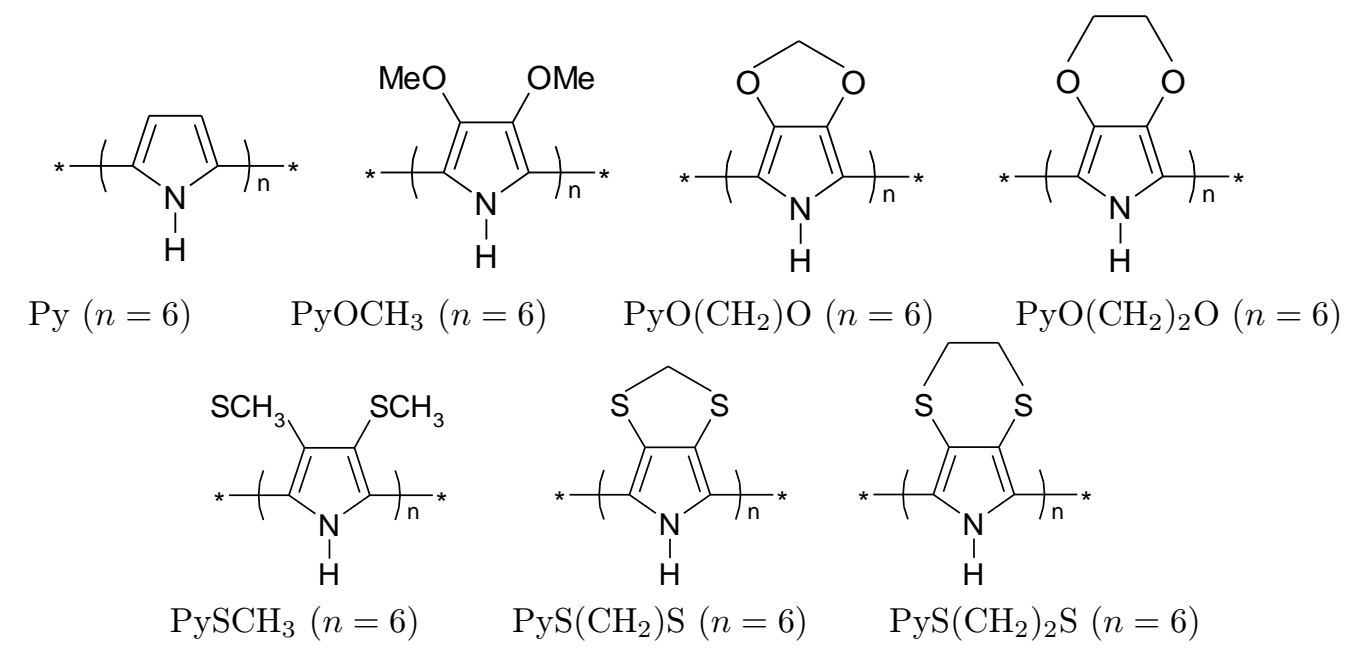

Fig. 1. Studied compounds.

\section{METHODOLOGY}

The DFT (density functional theory) methods were used in this study. These methods have become very popular in recent years because they can reach the exactitude similar to that reachable in other methods at a lesser time and expene from the computational point of view [22]. In agreement with the DFT results, the energy of the fundamental state of a polyelectronic system can be expressed through the total electronic density, and in fact, the use of electronic density instead of the wave function for calculating energy constitutes the fundamental base of the DFT. All calculations were done by GAUSSIAN $03 \mathrm{~W}$ software [27], using the B3LYP functional and a $6-31 \mathrm{G}^{*}$ basis set $[23-26]$. The B3LYP, a version of the DFT method, uses Becke's three-parameter functional (B3) and includes a mixture of $\mathrm{HF}$ with DFT exchange terms associated with the gradient corrected correlation functional of Lee, Yang, and Parr (LYP). The geometry of all species under investigation was determined by optimizing all the geometrical variables without any symmetry constraints. To obtain the charged (doped) oligopyrroles structures, we start from the optimized structures of the neutral form. The structures of neutral molecules are optimized under no constraint. We have also examined HOMO and LUMO levels; the energy gap is evaluated as the difference between the HOMO and LUMO energies. The excited states energies and oscillator strengths are investigated using the ZINDO/s $[28,29]$ and TD-DFT(B3LYP/6-31G(d)) [30-31] calculations on the fully optimized geometries. Radical cations are treated as open-shell systems and are computed using the UB3LYP/6-31G(d) wave functions. In fact, these calculations methods have been successfully applied to other $\pi$-conjugated materials [32].

\section{GEOMETRIC PROPERTIES}

For all molecules, geometrical parameters are obtained after the overall optimization by B3LYP/6-31G (d). It was found that the DFT-Optimized geometries were in excellent agreement with the data obtained from X-ray analyses. To investigate the effect of the substituents on the geometries and electronic properties, the optimized structures of several substituted oligomers built on pyrrole $\left(6 \mathrm{PyOCH}_{3}, 6 \mathrm{PySCH}_{3}, 6 \mathrm{PyS}\left(\mathrm{CH}_{2}\right) \mathrm{S}, 6 \mathrm{PyO}\left(\mathrm{CH}_{2}\right) \mathrm{O}\right.$, $6 \mathrm{PyS}\left(\mathrm{CH}_{2}\right)_{2} \mathrm{~S}$ and $\left.6 \mathrm{PyO}\left(\mathrm{CH}_{2}\right)_{2} \mathrm{O}\right)$ are compared with the unsubstituted one $6 \mathrm{Py}$. On the other hand, to investigate the effect of the ring structure, the optimized structures and the electronic properties of compounds $\left(6 \mathrm{PyOCH}_{3}, 6 \mathrm{PyO}\left(\mathrm{CH}_{2}\right) \mathrm{O}\right.$ and $\left.6 \mathrm{PyO}\left(\mathrm{CH}_{2}\right)_{2} \mathrm{O}\right)$ are compared with those of $\left(6 \mathrm{PySCH}_{3}, 6 \mathrm{PyS}\left(\mathrm{CH}_{2}\right) \mathrm{S}\right.$ and $\left.6 \mathrm{PyS}\left(\mathrm{CH}_{2}\right)_{2} \mathrm{~S}\right)$. The geometric characteristics set as inter-ring distances $(d i)$ and dihedral angles ( $u i$ ) (see Fig. 2) are listed in Table 1 and 2.

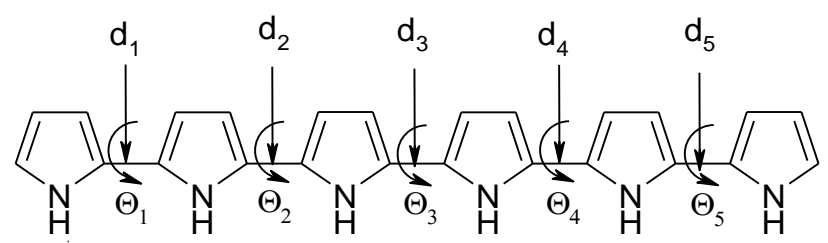

Fig. 2. Structures of the studied compounds and their geometric parameters.

The optimized geometrical structure of $6 \mathrm{Py}, 6 \mathrm{PyOCH}_{3}$, $6 \mathrm{PySCH}_{3},{ }_{6} \mathrm{PyS}\left(\mathrm{CH}_{2}\right) \mathrm{S}, 6 \mathrm{PyO}\left(\mathrm{CH}_{2}\right) \mathrm{O}, 6 \mathrm{PyS}\left(\mathrm{CH}_{2}\right)_{2} \mathrm{~S}$ and $\left.6 \mathrm{PyO}\left(\mathrm{wH}_{2}\right)_{2} \mathrm{O}\right)$ are displayed in Fig. 4. An accurate representation of the bond rotations in the chain is extremely important, since especially the properties of a polymer depend strongly on the conformational statistics of polymer chains. The theoretical calculations show that the inter-ring torsion angles are evaluated to be about $\approx$ $180^{\circ}$ (quasi planar conformation) for $6 \mathrm{Py}, 6 \mathrm{PyO}\left(\mathrm{CH}_{2}\right) \mathrm{O}$ and $\left.6 \mathrm{PyO}\left(\mathrm{CH}_{2}\right)_{2} \mathrm{O}\right)$. While other compounds with an antigauge with an average twist angle of about $173.2^{\circ}$ $\left(6 \mathrm{PyOCH}_{3}\right), 170.2^{\circ}\left(6 \mathrm{PySCH}_{3}\right), 161.8^{\circ}\left(6 \mathrm{PyS}\left(\mathrm{CH}_{2}\right) \mathrm{S}\right)$ and $151.9^{\circ}\left(6 \mathrm{PyS}\left(\mathrm{CH}_{2}\right)_{2} \mathrm{~S}\right)$. The passage of compounds $\left.6 \mathrm{Py}, 6 \mathrm{PyOCH}_{3}, 6 \mathrm{PyO}\left(\mathrm{CH}_{2}\right) \mathrm{O}, 6 \mathrm{PyO}\left(\mathrm{CH}_{2}\right)_{2} \mathrm{u}\right)$ to compounds $6 \mathrm{PySCH}_{3}, 6 \mathrm{PyS}\left(\mathrm{CH}_{2}\right) \mathrm{S}, 6 \mathrm{PyS}\left(\mathrm{CH}_{2}\right)_{2} \mathrm{~S}$ reduces 
the torsional angle. This can be explained by the strong hydrogen oxygen interaction which becomes weak in the case of sulfur hydrogen. The effect of substitution of pyrrole hydrogen in the $3 \mathrm{rd}$ and 4 th positions is clearly seen. However, the introduction of charges (substitution of pyrrole in $3 \mathrm{rd}$ and 4 th positions) carriers enhances the $\pi$-conjugated structures.

\begin{tabular}{|l|l|l|l|l|l|}
\hline Inter-ring distances $(\AA)$ & $d_{1}$ & $d_{2}$ & $d_{3}$ & $d_{4}$ & $d_{5}$ \\
\hline $6 \mathrm{Py}$ & 1.445 & 1.442 & 1.441 & 1.442 & 1.445 \\
\hline $6 \mathrm{PyOCH}_{3}$ & 1.437 & 1.435 & 1.435 & 1.435 & 1.437 \\
\hline $6 \mathrm{PySCH}$ & 1.453 & 1.454 & 1.454 & 1.453 & 1.452 \\
\hline $6 \mathrm{PyS}\left(\mathrm{CH}_{2}\right) \mathrm{S}$ & 1.441 & 1.439 & 1.438 & 1.439 & 1.441 \\
\hline $6 \mathrm{PyO}\left(\mathrm{CH}_{2}\right) \mathrm{O}$ & 1.435 & 1.432 & 1.432 & 1.432 & 1.435 \\
\hline $6 \mathrm{PyS}\left(\mathrm{CH}_{2}\right)_{2} \mathrm{~S}$ & 1.448 & 1.447 & 1.447 & 1.447 & 1.448 \\
\hline $6 \mathrm{PyO}\left(\mathrm{CH}_{2}\right)_{2} \mathrm{O}$ & 1.433 & 1.430 & 1.430 & 1.430 & 1.433 \\
\hline
\end{tabular}

Table 1. Inter-ring distances $d_{i}(\AA)$ of the studied compounds obtained by the B3LYP/6-31G(d) calculations.

\begin{tabular}{|l|l|l|l|l|l|}
\hline Dihedral angles $\left(^{\circ}\right)$ & $\theta_{1}$ & $\theta_{2}$ & $\theta_{3}$ & $\theta_{4}$ & $\theta_{5}$ \\
\hline $6 \mathrm{Py}$ & 179.9 & 179.9 & 179.9 & 179.9 & 179.9 \\
\hline $6 \mathrm{PyOCH}_{3}$ & 173.8 & 175.0 & 167.9 & 174.7 & 174.0 \\
\hline $6 \mathrm{PySCH}_{3}$ & 171.7 & 170.0 & 171.0 & 160.8 & 177.6 \\
\hline $6 \mathrm{PyS}\left(\mathrm{CH}_{2}\right) \mathrm{S}$ & 162.9 & 158.7 & 165.9 & 162.7 & 159.1 \\
\hline $6 \mathrm{PyO}\left(\mathrm{CH}_{2}\right) \mathrm{O}$ & 179.3 & 178.0 & 178.4 & 179.7 & 177.6 \\
\hline $6 \mathrm{PyS}\left(\mathrm{CH}_{2}\right)_{2} \mathrm{~S}$ & 156.1 & 148.1 & 150.5 & 148.1 & 156.6 \\
\hline $6 \mathrm{PyO}\left(\mathrm{CH}_{2}\right)_{2} \mathrm{O}$ & 179.6 & 179.5 & 179.9 & 179.5 & 179.6 \\
\hline
\end{tabular}

Table 2. Dihedral angles $\theta_{\mathrm{i}}\left(^{\circ}\right)$ of the studied compounds obtained by B3LYP/6-31G(d) calculations.
When we compare the inter-ring bond for the studied oligopyrroles, we note that in the case of $6 \mathrm{PySCH}_{3}$ and $6 \mathrm{PyS}\left(\mathrm{CH}_{2}\right)_{2} \mathrm{~S}$, the inter-ring distances increase while in the case of the other compounds and specially $6 \mathrm{PyOCH}_{3}$, $6 \mathrm{PyO}\left(\mathrm{CH}_{2}\right) \mathrm{O}$ and $6 \mathrm{PyO}\left(\mathrm{CH}_{2}\right)_{2} \mathrm{O}$ inter-ring distances decrease (Fig. 3). This can be explained by the Colombian interaction between oxygen and hydrogen and we can advance the assumption that the electronic properties of the last oligomers $\left(6 \mathrm{PyOCH}_{3}, 6 \mathrm{PyO}\left(\mathrm{CH}_{2}\right) \mathrm{O}\right.$ and $\left.6 \mathrm{PyO}\left(\mathrm{CH}_{2}\right)_{2} \mathrm{O}\right)$ will be responsible for this difference. This will be discussed in the second part.

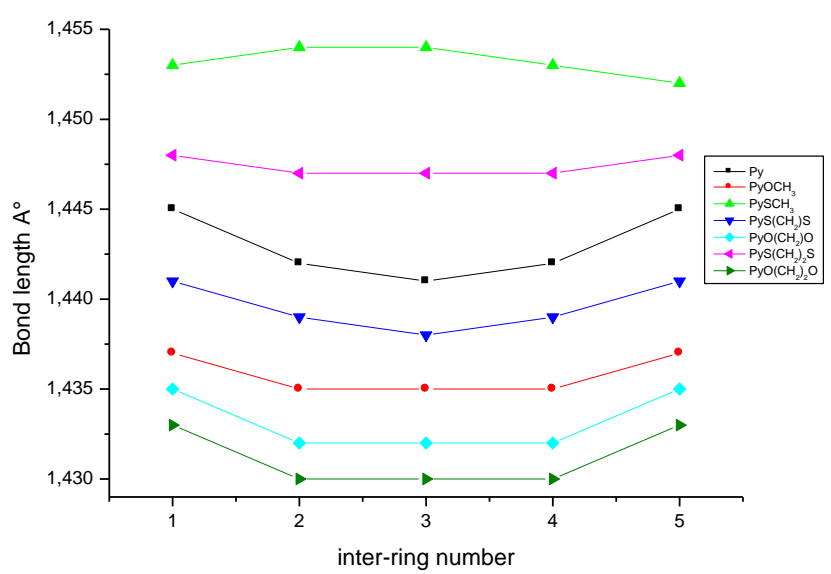

Fig. 3. (Color online) Optimized CC inter-ring bond lengths of neutral oligopyrrole.

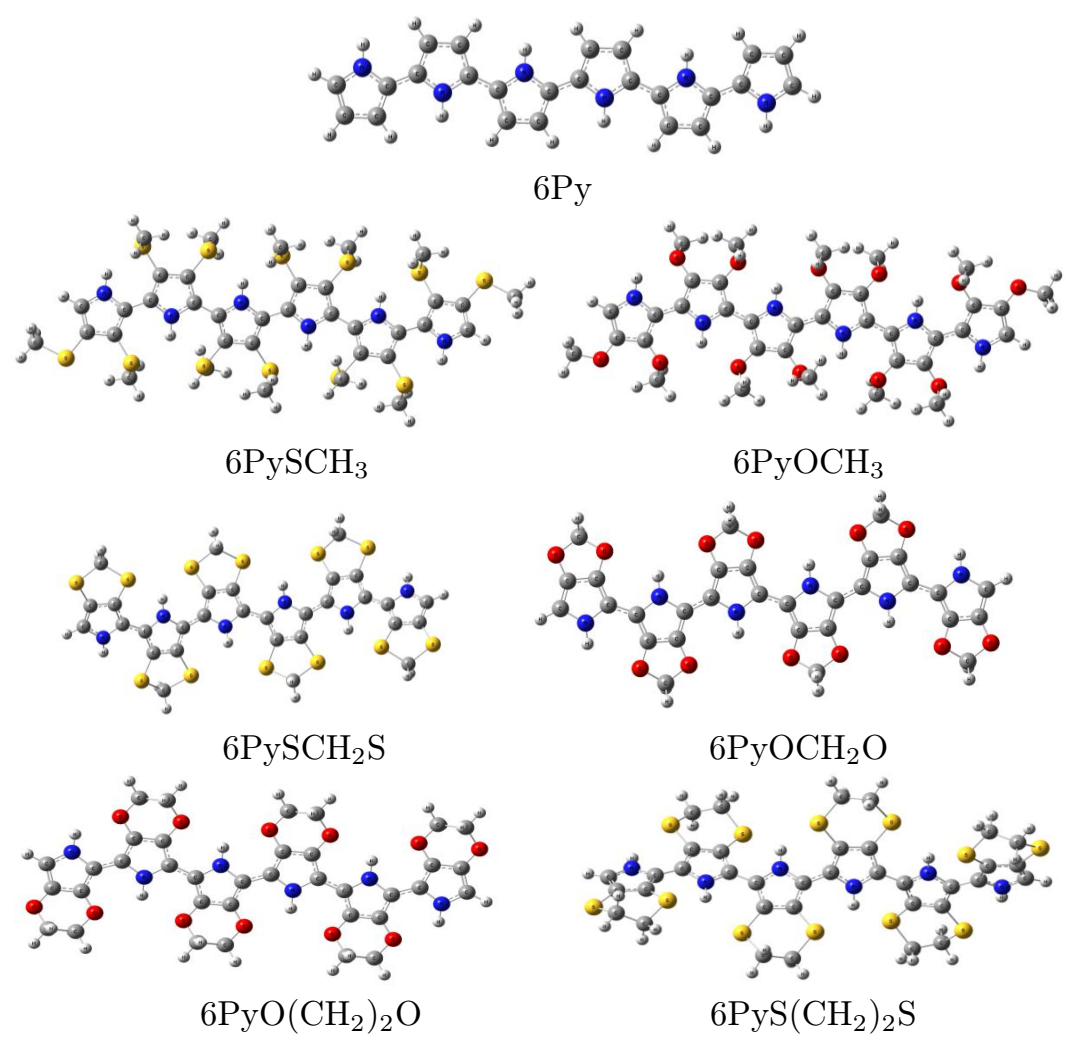

Fig. 4. (Color online) Optimized structures of the studied oligomers. 


\section{OPTO-ELECTRONIC PROPERTIES}

It is important to examine the HOMO and the LUMO energies for these oligomers because the relative ordering of the occupied and virtual orbital provides a reasonable qualitative indication of excitation properties. In gener- al, as shown in Fig. 5 (LUMO, HOMO), the HOMOs of these oligomers possess a $\pi$-bonding character within a subunit and a $\pi$-antibonding character between the consecutive sub-units. On the other hand, the LUMOs possess a $\pi$-antibonding character within sub-unit and a $\pi$-bonding character between the sub-units.

HOMO

\subsection{0\%}

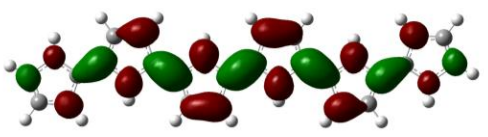

$6 \mathrm{Py}$
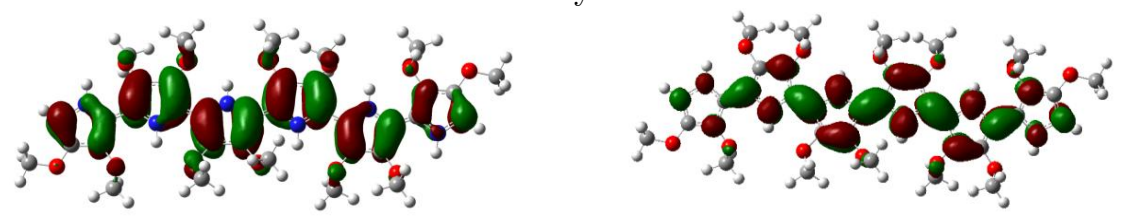

$6 \mathrm{PyOCH}_{3}$
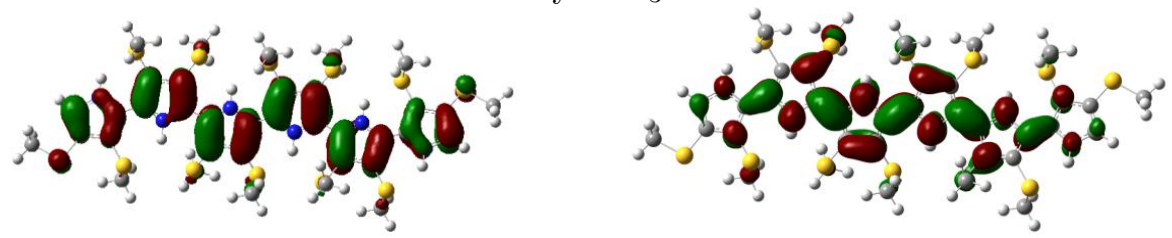

$6 \mathrm{PySCH}_{3}$
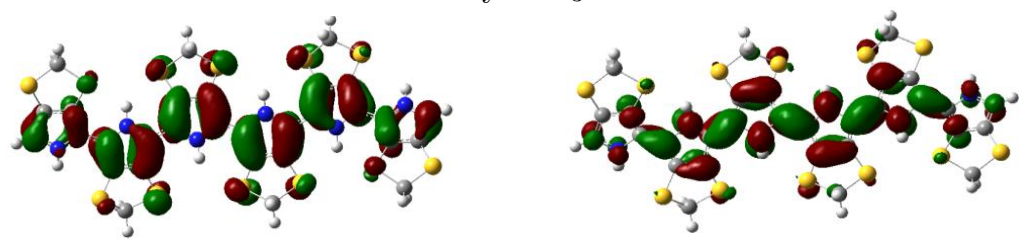

$6 \mathrm{PyS}\left(\mathrm{CH}_{2}\right) \mathrm{S}$
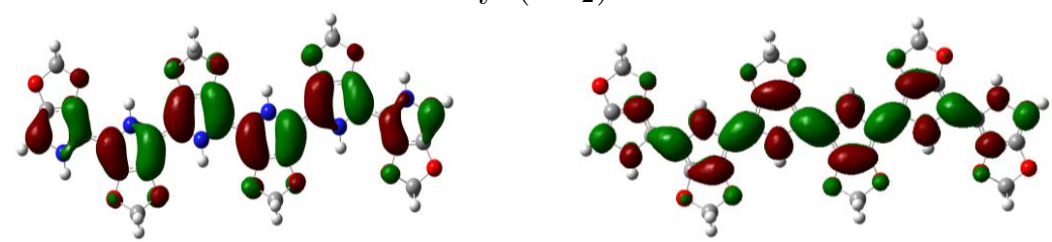

$6 \mathrm{PyO}\left(\mathrm{CH}_{2}\right) \mathrm{O}$
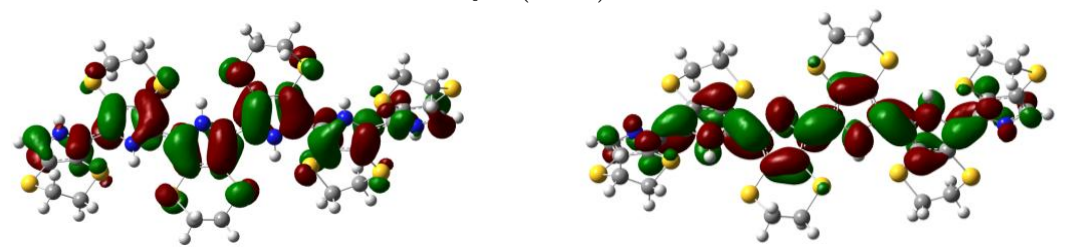

$6 \mathrm{PyS}\left(\mathrm{CH}_{2}\right)_{2} \mathrm{~S}$
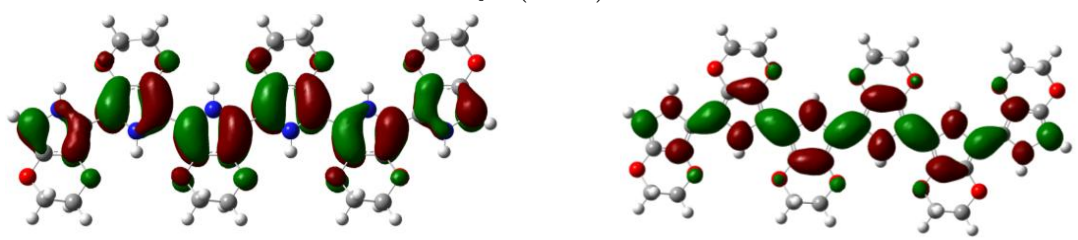

$6 \mathrm{PyO}\left(\mathrm{CH}_{2}\right)_{2} \mathrm{O}$

Fig. 5. (Color online) The contour plots of HOMO and LUMO orbital's of the studied compounds. 
The experiment shows that the HOMO and LUMO energies are obtained from an empirical formula based on the onset of the oxidation and reduction peaks measured by the cyclic voltametry. But in theory, the HOMO and LUMO energies can be calculated by the DFT calculation [33-34]. However, it is noticeable that solid-state packing effects are not included in the DFT calculations, which tend to affect the HOMO and LUMO energy levels in a thin film compared with an isolated molecule as considered in the calculations. Even if these calculated energy levels are not accurate, it is possible to use them to get the information by comparing similar oligomers or polymers.

\begin{tabular}{|l|c|c|c|}
\hline Molecule & $E_{\mathrm{HOMO}} / \mathrm{eV}$ & $E_{\mathrm{LuMO}} / \mathrm{eV}$ & $E_{\text {gap }} / \mathrm{eV}$ \\
\hline $6 \mathrm{Py}$ & -3.970 & -0.607 & 3.363 \\
$6 \mathrm{PyOCH}$ & -3.510 & -0.273 & 3.237 \\
$6 \mathrm{PySCH}_{3}$ & -4.468 & -1.000 & 3.468 \\
$6 \mathrm{PyS}\left(\mathrm{CH}_{2}\right) \mathrm{S}$ & -4.296 & -1.073 & 3.223 \\
$6 \mathrm{PyO}\left(\mathrm{CH}_{2}\right) \mathrm{O}$ & -3.879 & -0.689 & 3.190 \\
$6 \mathrm{PyS}\left(\mathrm{CH}_{2}\right)_{2} \mathrm{~S}$ & -4.030 & -0.639 & 3.391 \\
$6 \mathrm{PyH}\left(\mathrm{CO}_{2}\right)_{2} \mathrm{O}$ & -5.910 & -0.257 & 3.004 \\
\hline
\end{tabular}

Table 3. Values of HOMO (eV), LUMO (eV) and $E_{\text {gap }}(\mathrm{eV})$ energies calculated for $6 \mathrm{Py}, 6 \mathrm{PyOCH}_{3}$, $6 \mathrm{PySCH}_{3}, 6 \mathrm{PyS}\left(\mathrm{CH}_{2}\right) \mathrm{S}, 6 \mathrm{PyO}\left(\mathrm{CH}_{2}\right) \mathrm{O}, 6 \mathrm{PyS}\left(\mathrm{CH}_{2}\right)_{2} \mathrm{~S}$ and $\left.6 \mathrm{PyO}\left(\mathrm{CH}_{2}\right)_{2} \mathrm{O}\right)$.

The calculated electronic parameters (Gap, HO$\mathrm{MO}, \mathrm{LUMO}$ ) of compounds $6 \mathrm{Py}, 6 \mathrm{PyOCH}_{3}, 6 \mathrm{PySCH}_{3}$, $6 \mathrm{PyS}\left(\mathrm{CH}_{2}\right) \mathrm{S}, \quad 6 \mathrm{PyO}\left(\mathrm{CH}_{2}\right) \mathrm{O}, \quad 6 \mathrm{PyS}\left(\mathrm{CH}_{2}\right)_{2} \mathrm{~S}$ and $6 \mathrm{PyO}\left(\mathrm{CH}_{2}\right)_{2} \mathrm{O}$ are $(3.363 \mathrm{eV}, \quad 3.237 \mathrm{eV}, \quad 3.468 \mathrm{eV}$, $3.223 \mathrm{eV}, 3.19 \mathrm{eV}, 3.391 \mathrm{eV}$ and 3.004$) ;(-3.970 \mathrm{eV}$, $-3.510 \mathrm{eV},-4.468 \mathrm{eV},-4.296 \mathrm{eV},-3.879 \mathrm{eV},-4.030 \mathrm{eV}$ and $-5.910 \mathrm{eV})$ and $(-0.607 \mathrm{eV},-0.273 \mathrm{eV},-1.00 \mathrm{eV}$, $-1.073 \mathrm{eV},-0.639 \mathrm{eV}$ and $-0.257 \mathrm{eV})$, respectively. In the case of compounds $6 \mathrm{PyOCH}_{3}, 6 \mathrm{PyO}\left(\mathrm{CH}_{2}\right) \mathrm{O}$ and $6 \mathrm{PyO}\left(\mathrm{CH}_{2}\right)_{2} \mathrm{O}$ one remarks that there is a systematic change of the HOMO and LUMO energies into the backbone, the substitution pushes upward or downward the HOMO/LUMO energies in agreement with their electron donor character. However, these compounds have a smaller energy gap (Eg) than the unsubstituted one $6 \mathrm{Py}$, which is due to the presence of different substituents as described previously [35]. The band gap of $\left.6 \mathrm{PyO}\left(\mathrm{CH}_{2}\right)_{2} \mathrm{O}\right)$ is much smaller than that of the other substituted compounds. This may be attributed to the number of electron-donating Ethylene dioxy side groups and also to the Coulombic interaction between hydrogen of nitrogen and oxygen atoms [36]. Concerning the comparison between the compounds $6 \mathrm{PyOCH}_{3}$ and $6 \mathrm{PySCH}_{3}$, the theoretical HOMO, LUMO and Gap energies of $6 \mathrm{PyOCH}_{3}$ are $-3.51 \mathrm{eV},-0.27 \mathrm{eV}$ and $3.23 \mathrm{eV}$; while those of $6 \mathrm{PySCH}_{3}$, are $-4.46 \mathrm{eV},-1.00 \mathrm{eV}$ and $3.22 \mathrm{eV}$, respectively, as shown in table 3 . It suggests that the replacement of oxygen atoms in, $6 \mathrm{PyOCH}_{3}$, $6 \mathrm{PyO}\left(\mathrm{CH}_{2}\right) \mathrm{O}$, and $\left.6 \mathrm{PyO}\left(\mathrm{CH}_{2}\right)_{2} \mathrm{O}\right)$ by sulphur atoms leads to the stabilisation of both the HOMO and LUMO levels (see fig. 6) with an increase in the energy Gap. This is in agreement with the experimental results described elsewhere [35]. These results can explain the short values of di obtained in the case of $6 \mathrm{PyOCH}_{3}, 6 \mathrm{PyO}\left(\mathrm{CH}_{2}\right) \mathrm{O}$, and $\left.6 \mathrm{PyO}\left(\mathrm{CH}_{2}\right)_{2} \mathrm{O}\right)$.

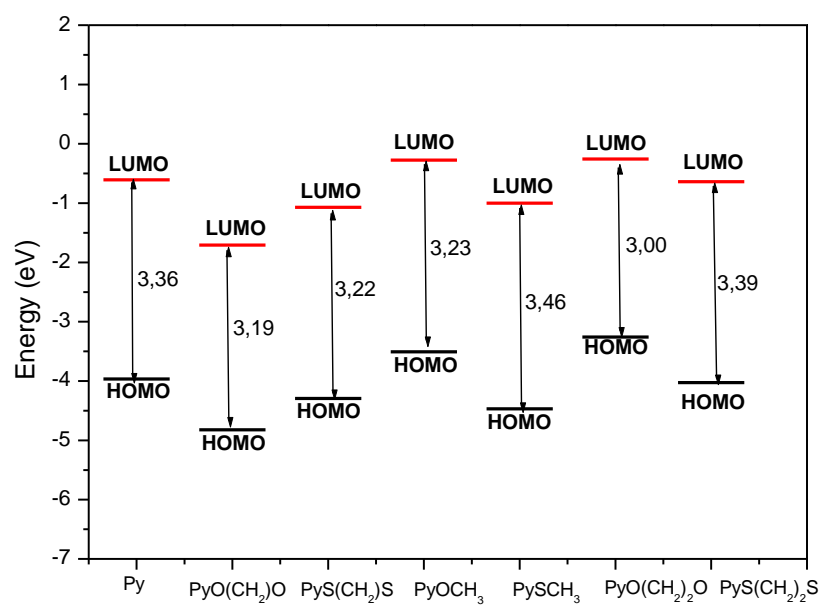

Fig. 6. Schematic representation of the B3LYP/6-31G(d) calculated energies HOMO and LUMO Levels of the studied oligomers.

To investigate the substitution effect on the absorption properties of these oligomers, the values of $\lambda_{\max }$ are presented in Table 4. These values are calculated by TDDFT, and ZINDO methods starting with an optimized geometry obtained at the B3LYP/6-31G(d) level. At the first glance over the numbers we notice that the calculated values of $\lambda_{\max }$ shift in the same direction upon the substitution by $\mathrm{OCH}_{3}, \mathrm{O}\left(\mathrm{CH}_{2}\right) \mathrm{O}$ or $\mathrm{O}\left(\mathrm{CH}_{2}\right)_{2} \mathrm{O}$ whatever the applied method maybe. All the substituted oligomers $6 \mathrm{PyOCH}_{3}, 6 \mathrm{PyO}\left(\mathrm{CH}_{2}\right) \mathrm{O}$, and $6 \mathrm{PyO}\left(\mathrm{CH}_{2}\right)_{2} \mathrm{O}$ exhibit a red shift relative to the unsubstituted one $6 \mathrm{Py}$. This is in good agreement with the obtained results in the first part and with the experimental observations [37]. We note that calculations are performed in the isolated state, while the properties are measured in a liquid state. The theoretical wavelengths $\left(\lambda_{\max }\right)$ calculated for isolated chains are expected to be about $25 \mathrm{~nm}$ smaller than the experimental values obtained from the condensed phase's approach [38]. When taking into consideration this difference, the TDDFT method tends to reproduce the best $\lambda_{\max }$ values similar to those of the experience.

\section{THE DOPING PROCESS}

Within the context of molecular electronics, studies on the structure of a charged oligopyrrole are relevant to Holt transport through single molecules since this process can be regarded as a result of the p-doping of the semi-conducting molecule. Since the p-doped molecule becomes ultimately responsible for charged transport it is interesting to study this phenomenon in our case. As said before, to obtain the oxidized optimized structure of a oligopyrrole and its derivatives we started from the optimized structure of the neutral form. When compared with the neutral oligomers, the simple bonds become shorter, while the double ones become longer. The interrings bonds are longer than normal double bonds. 
H. TOUFIK, S. M. BOUZZINE, O. NINIS, et al.

\begin{tabular}{|l|l|c|}
\hline Molecule & Methods & $\lambda_{\max }(\mathrm{nm})$ cal, (O. S) \\
\hline 6Py & TD//B3LYP/6-31G(d) & $409.05(1.93)$ \\
& ZINDO & $485.17(1.75)$ \\
$6 \mathrm{PyOCH}_{3}$ & TD//L3BYP/6-31G(d) & $423.27(1.89)$ \\
& ZINDO & $513.97(1.58)$ \\
$6 \mathrm{PySCH}_{3}$ & TD//B3LYP/6-31G(d) & $402.47(1.28)$ \\
& ZINDO & $483.80(1.59)$ \\
$6 \mathrm{PyS}\left(\mathrm{CH}_{2}\right) \mathrm{S}$ & TD//B3LYP/6-31G(d) & $435.70(1.45)$ \\
& ZINDO & $488.32(1.50)$ \\
$6 \mathrm{PyH}\left(\mathrm{CO}_{2}\right) \mathrm{O}$ & TD//B3LYP/6-31G(d) & $407.96(2.18)$ \\
& ZINDO & $519.23(1.74)$ \\
$6 \mathrm{PyS}\left(\mathrm{CH}_{2}\right)_{2} \mathrm{~S}$ & TD//B3LYP/6-31G(d) & $415.34(1.31)$ \\
& ZINDO & $467.34(1.42)$ \\
$6 \mathrm{PyO}\left(\mathrm{CH}_{2}\right)_{2} \mathrm{O}$ & TD//B3LYP/6-31G(d) & $453.35(2.11)$ \\
& ZINDO & $532.88(1.65)$ \\
\hline
\end{tabular}

Table 4. Calculated absorption $\lambda_{\max }(\mathrm{nm})$ and Oscillator Strength (O.S) for $\left.6 \mathrm{Py}, 6 \mathrm{PyOCH}_{3}, 6 \mathrm{PySCH}_{3}, 6 \mathrm{PyS} \mathrm{CH}_{2}\right) \mathrm{S}$, $6 \mathrm{PyO}\left(\mathrm{CH}_{2}\right) \mathrm{O}, 6 \mathrm{PyS}\left(\mathrm{CH}_{2}\right)_{2} \mathrm{~S}$ and $\left.6 \mathrm{PyO}\left(\mathrm{CH}_{2}\right)_{2} \mathrm{O}\right)$.

\begin{tabular}{|l|c|c|c|}
\hline Molecule & $E_{\mathrm{Gap}} / \mathrm{eV}$ (neutre) & $E_{\mathrm{Gap}} / \mathrm{eV}$ (Polaron) & $E_{\text {gap }} / \mathrm{eV}$ (Bipolaron) \\
\hline $6 \mathrm{Py}$ & 3.363 & 3.07 & 1.06 \\
$6 \mathrm{PyOCH}_{3}$ & 3.237 & 2.97 & 1.26 \\
$6 \mathrm{PySCH}_{3}$ & 3,468 & 3.17 & 0.72 \\
$6 \mathrm{PyS}\left(\mathrm{CH}_{2}\right) \mathrm{S}$ & 3.223 & 2.86 & 0.98 \\
$6 \mathrm{PyO}\left(\mathrm{CH}_{2}\right) \mathrm{O}$ & 3.190 & 2.95 & 1.10 \\
$6 \mathrm{PyS}\left(\mathrm{CH}_{2}\right)_{2} \mathrm{~S}$ & 3.391 & 2.88 & 1.02 \\
$6 \mathrm{PyO}\left(\mathrm{CH}_{2}\right)_{2} \mathrm{O}$ & 3.004 & 2.75 & 1.25 \\
\hline
\end{tabular}

Table 5. The values of energy Gap $(\mathrm{eV})$ of several oligomers, respectively, in their neutral, polaronic and bipolaronic forms.

A quinoid-like distortion emerges as a result of oxidation (Fig. 6). The region with a clearly distinct quinoid structure extends over four-six pyrrole rings, which is consistent with the ab-initio HF and DFT calculations performed by J. Casado et al. [39] for substituted oligopyrroles. On the other hand, the optimized geometry of the dicationic oligopyrrole and derivatives indicates the formation of the positive bipolaron defect localized in the middle of the molecule and extends over the adjacent repeated units. The charged species are characterized by a reverse of the single double $\mathrm{C}-\mathrm{C}$ bond pattern; the geometry process thus induces the appearance of a strong quinoid character within the molecule (Fig. 4).

For example, structural parameters of the $6 \mathrm{Py}$ in its quinoidic form (polaronic and bipolaronic) indicate that the cycles at the ends preserve their aromatic character whereas the central processing units present a quinoid character. For the oxidized $(6 \mathrm{Py})^{\cdot+}$, the four innermost rings are characterized by a quinoidic structure. This is summarized on figure 6 .

Traditionally up until now the charged states the conjugated molecules have been discussed in terms of the one-electron band model. The values of the gap energies are shown in Table 5 for several oligomers in their neutral, polaronic and bipolaronic forms, respectively. The available values of the gap energy of polymer in a neural state are presented also in this Table for comparison. We note that the energy gap decreases when passing from the neutral to the doped form for all oligomers.
More importantly, these properties can be tuned by different substituents in several positions. On the other hand, theoretical calculations provide a lot of useful information that help the chemists to build up a good relationship between structure and properties of these materials. A theoretical analysis of the electronic structures of various conjugated polymers and oligomers has been extensively reported [41-43]. We have successfully used the DFT method to predict the properties of polythiophene and polyparaphenylene $[44,45]$.<smiles>[R7]c1c[nH]c(-c2[nH]c(-c3[nH]c(-c4[nH]c(-c5[nH]c(-c6[nH]cc(P)c6[R])c([R])c5[R])c([R])c4[2H])c([R])c3[R])c([R])c2[R])c1[R]</smiles>

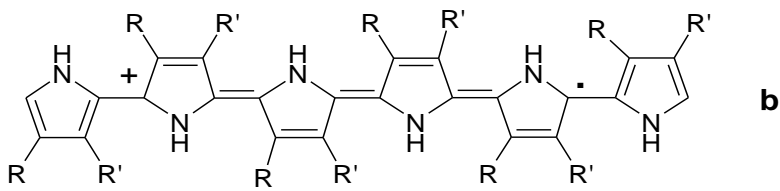

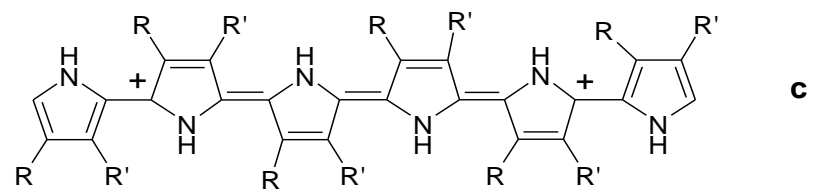

Fig. 7. Simplified neutral (a), polaron (b) and bipolaronic (c) structures. 


\section{CONCLUSION}

In the present paper, a theoretical model of a oligopyrrole and derivatives is obtained from the B3LYP $/ 6-31(\mathrm{~d})$ calculations. The most stable confirmation in the neutral form is the anti-planar conformation for all the studied molecules. For polaron and bipolaron oligomers, the obtained structures are completely planar. The gap energy calculated with the same method decreases when passing from the neutral to the doped form for each oligomer. The quinoidic character is more accentuated when a second electron is removed. The effect of the substituent $\mathrm{OCH}_{3}, \mathrm{SCH}_{3}, \mathrm{~S}\left(\mathrm{CH}_{2}\right) \mathrm{S}, \mathrm{O}\left(\mathrm{CH}_{2}\right) \mathrm{O}, \mathrm{S}\left(\mathrm{CH}_{2}\right)_{2} \mathrm{~S}$ and $\mathrm{O}\left(\mathrm{CH}_{2}\right)_{2} \mathrm{O}$ groups in the 3rd and 4th positions of a pyrrole have been examined. The insertion of $\mathrm{OCH}_{3}$,
$\mathrm{S}\left(\mathrm{CH}_{2}\right) \mathrm{S}, \mathrm{O}\left(\mathrm{CH}_{2}\right) \mathrm{O}$ and $\mathrm{O}\left(\mathrm{CH}_{2}\right)_{2} \mathrm{O}$ groups leads to a reduction of the energy gaps. The obtained results lead to suggest that these oligomers are good models to reflect the optoelectronic properties for the corresponding parent polymer. On the other hand, our calculations have shown geometrical changes after one and two electron oxidations and have specified the atoms and bonds in oligomers, which are the most sensitive to these changes. The lateral pyrrole rings do not reveal any geometrical changes after the doping process. These theoretical results help us to interpret electrochemical experiments and to predict molecular properties also for neutral, polaronic and bipolaronic states leading to the future application of these compounds.
[1] G. Horowitz, M. E. Hajlaoui, Adv. Mater. 12, 1046 (2000); H. Meng, J. Zheng, A. J. Lovinger, B. C. Wang, P. G. Van Patten, Z. Bao, Chem. Mater. 15, 1778 (2003); M. Mushrush, A. Facchetti, M. Lefenfeld, H. E. Katz, T. J. Marks, J. Am. Chem. Soc. 125, 9414 (2003).

[2] M. Pasini, S. Destri, W. Porzio, C. Botta, U. Giovanella, J. Mater. Chem. 13, 807 (2003); M. Suzuki, M. Fukuyama, Y. Hori, S. Hotta, J. Appl. Phys. 91, 5706 (2002); I. F. Perepichka, D. F. Perepichka, H. Meng, F. Wudl, Adv. Mater. 17, 2281 (2005); Q. B. Pei, Y. Yang, J. Am. Chem. Soc. 118, 7416 (1996); A. Xia, Z. Yuan, S. T. Tan, Y. P. Zou, Z. A. Tan, Y. Yang, Y. F. Li, Eur. Polym. J. 43, 1394 (2007).

[3] D. Pisignano, M. Anni, G. Gigli, R. Cingolani, M. Zavelani-Rossi, G. Lanzani, G. Barbarella, L. Favaretto, Appl. Phys. Lett. 81, 3534 (2002).

[4] L. Torsi, A. J. Lovinger, B. Crone, T. Someya, A. Dodabalapur, H. E. Katz, A. Gelperin, J. Phys. Chem. B 106, 12563 (2002); J. Roncali, J. Mater. Chem. 9, 1875 (1999); X. H. Zhou, J. C. Yan, J. Pei, Macromolecules 37, 7078 (2004); T. Yasuda, I. Yamaguchi, T. Yamamoto, Adv. Mater. 15, 293 (2003).

[5] N. Noma, T. Tsuzuki, Y. Shirota, Adv. Mater. 7, 647 (1995); C. Videlot, A. El Kassmi, D. Fichou, Solar Energy Mater. Solar Cells 6369 (2000); K. Hara, M. Kurashige, Y. Dan-Oh, C. Kasada, A. Shinpo, S. Suga, K. Sayama, H. Arakawa, New J. Chem. 27, 783 (2003); J. Ackermann, C. Videlot, A. El Kassmi, R. Guglielmetti, F.'Fages, Adv. Mater. 16, 1709 (2004); J. H. Hou, Z. A. Tan, Y. Yan, Y. J. He, C. H. Yang, Y. F. Li, J. Am. Chem. Soc. 128, 4911 (2006); S. L. Lu, M. J. Yang, J. Luo, Y. Cao, F. L. Bai, Macromol. Chem. Phys. 206, 664 (2005); K. L. Sang, S. C. Nam, H. K. Joong, S. L. Koeng, K. S. Hong, D. H. Hwang, J. B. Christoph, Thin Solid Films 158, 511 (2006); X. Y. Deng, L. P. Zheng, C. H. Yang, Y. F. Li, G. Yu, Y. Cao, J. Phys. Chem. B. 108, 3451 (2004); S. S. Sun, C. Zhang, A. Ledbetter, S. Choi, K. Seo, C. E. Bonner, J. M. Drees, N. S. Sariciftci, Appl. Phys. Lett. 90, 43117 (2007).

[6] A. F. Diaz, K. K. Kanazawa, G. P. Gardini, J. Chem. Soc., Chem. Commun., 183 (1988); K. K. Kanazawa, A. F. Diaz, W. D. Gill, P. H. Grant, G. B. Street,
G. P. Gardini, J. F. Kwak, Synuth. Met. 1, 329 (1980).

[7] L. P. Prezyna, Y. J. Qiu, J. R. Reynolds, G. E. Wnek, Macromoleculares 24, 5283 (1991).

[8] S. K. Ghoshal, Chem. Phys. Lett. 158, 65 (1989).

[9] B. Z. Lubentsov, G. I. Zvereva, Ya. H. Samovarov, S. M. Bystriak, O. N. Timofeeva, M. L. Khidekel, Synth. Metalls 41, 1143 (1991).

[10] T. C. Pearce, J. W. Gardner, S. Friel, P. N. Bartlett, N. Blair, Analyst. 118, 371 (1993); P. Evans, N. M. Ratcliffe, J. R. Smith, S. A. Campbell, J. Mater. Chem. 6, 295 (1996).

[11] P. R. Teasdale, G. G. Vallace, Analyst. 118, 329 (1993).

[12] E. V. Thillo, G. Defieuw, W. de. Winter, Bull. Soc. Chim. Belg. 99, 981 (1990).

[13] C. J. Gow, C. F. Zukoski, J. Colloid Interface Sci. 136, 175 (1990).

[14] T. Sata, T. Yamaguchi, K. Matsusaki, J. Phys. Chem. 100, 16633 (1996).

[15] G. C. Teare, N. M. Ractcliffe, J. Mater. Chem. 6, 301 (1996).

[16] J. R. Ghimaraes, J. G. Amazonas, C. A. B. Silva Junior, C. P. Melo, J. D. Nero, Mat. Sci. Eng. 28, 1076 (2008).

[17] P. Bäurele In: K. Müllen, G. Wegner, Editors, Electronic Materials: The oligomer Approach, Wiley-VCH, Weinheim, NY (1998).

[18] J. Ma, S. Li, Y. Jiang, Macromolecules. 35, 1109 (2002).

[19] S. M. Bouzzine, M. Hamidi, M. Bouachrine, Orbital. 2, 203 (2009).

[20] H. Zgou, S. M. Bouzzine, S. Bouzakraoui, M. Hamidi, M. Bouachrine, Chin. Chem. Lett. 19, 123 (2008).

[21] A. Cravino, N. S. Sariciftci, J. Mater. Chem. 12, 1931 (2002).

[22] R. Ditchfield, W. J. Hehre, J. A. Pople, J. Chem. Phys. 54, 76 (1971).

[23] A. D. Becke, J. Chem. Phys. 98, 5648 (1993).

[24] W. J. Hehre, R. Ditchfiesld, J. A. Pople, J. Chem. Phys. 56, 643 (1972).

[25] P. C. Hariharan, J. A. Pople, Mol. Phys. 27, 209 (1974).

[26] M. S. Gordon, Chem. Phys. Lett. 76, 33 (1980).

[27] M. J. Frisch et al., GAUSSIAN 03, Revision B. 04 (Gaussian, Inc., Pittsburgh PA, 2003).

[28] M. C. Zener, in Reviews in Computational Chemistry, Vol. 2, edited by K. B. Lipkowitz, D. B. Boyd (VCH 
Publishing, New York, 1991), p. 313.

[29] M. A. Thompson, M. C. Zener, J. Am. Chem. Soc. 113, 8210 (1991).

[30] L. Bartolloti, J. Phys. Rev 26, 2243 (1982).

[31] E. Runge, E. K. U. Gross, Phys. Rev. Lett. 52, 997 (1984).

[32] M. E. Casida, Recent Advances in Density Functional Methods, Vol. 1, edited by D. P. Chang (World Scinetific, Singapore, 1995).

[33] H. Zgou, M. Hamidi, M. Bouachrine, Phys. Chem. News 32, 81 (2006).

[34] L. Yang, J. Feng, A. Ren, Polymer 46, 10970 (2005); J. L. Bredas, R. Silbey, D. S. Boudreaux, R. R. Chance, J. Chem. Soc. 105, 6555 (1983).

[35] D. Fichou, G. Horowitz, F. Garnier, Synth. Metalls 39, 125 (1990); D. Fichou, G. Horowitz, Y. Nishikitani, F. Garnier, Synth. Metalls 28, 66 (1989).

[36] M. Nisoli, V. Pruneri, S. De Silvestri, V. Magni, A. M. Gallazzi, C. Romanoni, G. Zerbi, G. Zotti, Chem. Phys. Lett. 220, 64 (1994).
[37] H. Li, C. Lambert, R. Stahl, Macromolecules 39, 2049 (2006).

[38] U. Salzner, J. B. Lagowski, P. G. Pickup, R. A. Poirier, Synth. Metalls 96, 17 (1998).

[39] J. Casado, V. Hernàndez, F. J. Ramirez, J. T. López, Navarrete, J. Mol. Structure: (THEOCHEM) 463, No 1-2, 211 (1999).

[40] V. Hernandez, D. Grebner, M. Helbig, S. Rentsh, Chem. Phys. 201, 309 (1995).

[41] F. C. Grozema, L. P. Candeias, M. Swart, P. Van Duijnen, J. Wildemen, G. Hadziioanou, J. Chem. Phys. 117, 11366 (2002).

[42] C. Alemán, E. Armelin, J. I. Iribarren, F. Liesa, Synth. Met. 149, 151 (2005).

[43] S. M. Bouzzine, S. Bouzakraoui, M. Bouachrine, M. Hamidi, J. Mol. Structure: (THEOCHEM) 726, №13, 271 (2005).

[44] S. Bouzakraoui, S. M. Bouzzine, M. Bouachrine, M. Hamidi, J. Mol. Structure: (THEOCHEM) 851, №13,254 (2008).

\title{
ОПТИКО-ЕЛЕКТРОННІ ВЛАСТИВОСТІ Й МОЛЕКУЛЯРНИЙ ДИЗАЙН НОВИХ МАТЕРІАЛІВ НА ОСНОВІ ПІРОЛУ. ДОСЛІДЖЕННЯ МЕТОДОМ ФУНКЦІОНАЛА ГУСТИНИ
}

\author{
Х. Туфік ${ }^{1}$, С. М. Буззіне ${ }^{2,3}$, O. Нініс ${ }^{1,4}$, М. Абаркане ${ }^{4}$, Ф. Лямшурі ${ }^{1}$, M. Хаміді $^{2}$, М. Буашріне \\ ${ }^{1}$ UMIM, Полідисциплінарний факультет, Таза, Марокко \\ ${ }^{2}$ UCTA, Факультет науки і техніки, Еррашідія, Марокко \\ ${ }^{3}$ Навчальній центр для вчителів, Еррашідія, Марокко \\ ${ }^{4}$ LIMAO, Полідисииплінарний факультет, Таза, Марокко
}

Теоретично досліджено геометрію та електронні властивості нових сполук із подвійними спряженими зв'язками на основі піролу в нейтральних і легованих станах. Теоретичні дані про геометрію основного стану та електронну структуру досліджуваних молекул отримано методом функціонала густини на рівні B3LYP з базисом 6-31G(d). Оптоелектронні властивості було визначено за допомогою ZINDO/s- i TD// B3LYP/6$31 \mathrm{G}(\mathrm{d})$-розрахунків, виконаних у B3LYP/6-31(d) оптимізованій геометрії. Обговорено вплив замінників та легування на геометрії та електронні властивості цих матеріалів. Результати цього дослідження показують, як електронні властивості можуть бути налаштовані за допомогою магістрального кільця або бічної групи і дають підставу вважати ці сполуки хорошими кандидатами для оптико-електронних пристроїв. 